\title{
Syzygium cumini (jamun) therapeutic potential: a comprehensive review on phytochemical constituents and emphasis on its pharmacological actions related to diabetic intervention
}

\author{
Meharban Asanaliyar, Pratibha Nadig*
}

Department of Pharmacology, Vydehi Institute of Medical Science and Research Centre, Whitefield, Bangalore, India

Received: 20 November 2019

Accepted: 07 January 2020

\author{
*Correspondence: \\ Dr. Pratibha Nadig, \\ Email: drpratibhanadig@yahoo.co.in
}

Copyright: () the author(s), publisher and licensee Medip Academy. This is an open-access article distributed under the terms of the Creative Commons Attribution Non-Commercial License, which permits unrestricted non-commercial use, distribution, and reproduction in any medium, provided the original work is properly cited.

\begin{abstract}
Syzygium cumini or Eugenia Jambolana Lam is a traditional medicinal plant very native to the Indian and Asian subcontinent. It is commonly known as black plum or jamun. Various plants parts of the tree are known for ethnomedicinal uses, and in particular, the fruits of Jamun tree are well known for medicinal uses and preparation of health drinks. Studies have shown that the berries contain carbohydrates, minerals and the pharmacologically active phytochemicals. The active phytochemical includes flavonoids, terpenes, and anthocyanins. Ayurvedic and Indian Folk Medicine have already mentioned the use of jamun for diabetic treatment even before the advent of insulin. The bark, fruit pulp, seeds and the leaves are evaluated in the crude form as well as extracts in various diabetic models. Further, bioactive phytochemicals are extracted using in vitro assays, some of them such as vitalboside-A, mycominose are also characterized with spectroscopic analysis. This review article is intended to compile Syzygium cumini's therapeutic potential with special emphasis on the phytochemical constituents and its pharmacological activities related to diabetic intervention through recent studies conducted in last one decade. It also addresses the clinical and toxicological studies.
\end{abstract}

Keywords: Syzygium cumini, Diabetes mellitus, Phytochemicals, Anthocyanins

\section{INTRODUCTION}

Syzygium cumini (SC) belongs to the member of the Myrtraceae family and it is native to India, Burma and Sri-Lanka. It is botanically synonymous with $\mathrm{S}$. jambolanum DC, Eugenia cumini. The common names of jamun plant include java plum, Portuguese plum, Malabar plum, black plum, purple plum, damson plum and Indian blackberry. In India, it is variously known as jamun, jambu, jambul, jambool, and jambhool.

Various plants parts of the tree are known for ethnomedicinal uses, and in particular, the fruits of SC tree are well known for medicinal uses and preparation of health drinks. Studies have shown that the berries contain carbohydrates, minerals and the pharmacologically active phytochemicals. The active phytochemical includes flavonoids, terpenes, and anthocyanins. Ayurvedic and Indian Folk Medicine have elaborated the use of SC for the diabetic treatment much before the advent of insulin. The different extracts of this plant have demonstrated to have a broad range of therapeutic potential including antibacterial, antifungal, antiviral, anti-genotoxic, antiinflammatory, anti-ulcerogenic, cardio protective, antiallergic, anticancer, chemo preventive, radio protective, free radical scavenging, antioxidant, hepatoprotective, anti-diarrheal, hypoglycaemic and antidiabetic effects. 

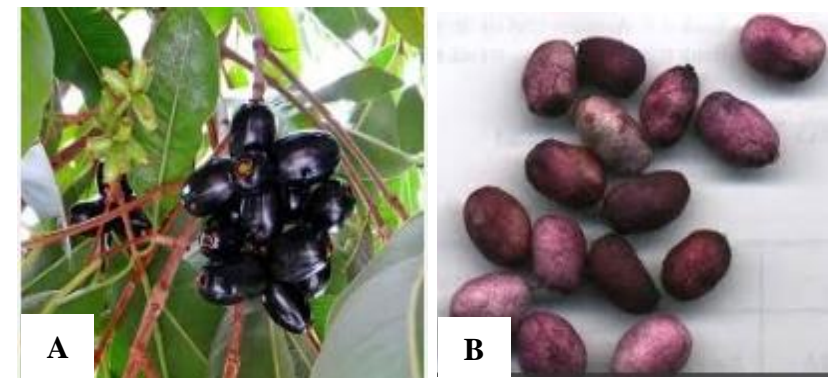

Figure 1 (A and B): Part of SC plants.

Anti-diabetic activity appears to be the most widely investigated pharmacological activity, based on which many traditional and proprietary Ayurvedic formulations are being prescribed and marketed.

This plant has been reviewed by many authors as far as its traditional use and pharmacological properties are concerned. Some authors have also reviewed the phytochemical constituents. However, the traditional uses linked to various parts of the plants, validation of the properties of the extracts obtained from various solvents and the most relevant phytochemical constituents related to antidiabetic activity have not been addressed comprehensively. Further there is limited literature covering the molecular mechanism of actions and clinical studies of these extracts. Hence this review will address these gaps in the research conducted with this plant so that further research can be carried out.

The review will mostly focus on the phytochemical constituents, pharmacological activities and mechanism of actions related to diabetic intervention reported for SC during the last one decade of research papers documented in the literature.

\section{PHYTOCHEMICAL COMPOSITION}

Medicinal plants exert their pharmacological actions and therapeutic uses through the active chemical constituents or secondary metabolites present in the plant parts. Most of traditional medicine systems like folklore medicine, household remedies, and Ayurveda, Siddha and Unani systems use the plant's parts as the crude mixture without isolating pharmacologically active principle for the treatment. Many researchers have reported active phytochemical present in various parts of SC. The plant is reported to have flavonoids, glycosides, phenolic compounds, anthocyanins, ellagic acid, quercetin, myricetin, kaemferol and jambolin by various extraction and spectroscopic methods. ${ }^{1}$

Sanches et al evaluated the hydroethanolic extract of SC leaves for phytochemical characterization and reported that it is rich in phenolic compounds through HPLC-MS or MS profiling at $254 \mathrm{~nm}$ and identified 15 compounds of hydrolysable tannins and flavonol subclasses. ${ }^{2}$
The bioassay-guided fractionation study using in vitro $\alpha$ amylase inhibitory assay (with 20 to $1000 \mu \mathrm{g} / \mathrm{ml}$ test material) with isolated compounds from ethyl acetate extract (EASc) of SC leaves led to the identification of ursolic acid and oleanolic acid as active constituents responsible for $\alpha$-amylase inhibitory activity. Chromatographic separation of ethyl acetate extract (EASc) of SC leaves led to identification of active fraction which inhibited both $\alpha$-amylase and glucosidase enzyme. The structural elucidation of isolated compounds was done using ${ }^{1} \mathrm{H}$ NMR and ${ }^{13} \mathrm{C}$ NMR spectroscopic analysis and also compared with authentic samples by TLC and HPLC methods. The bioactive fraction exhibited 3:1 mixture of ursolic acid and oleanolic acid and these finding suggested that inhibition of $\alpha$-amylase and $\alpha$ glucosidase enzyme by bioactive constituents of SC leaves may play key role in antidiabetic therapy intervention. ${ }^{3}$

Phytochemical characterization and comprehensive study of the phenolic composition of the edible parts of jambolana fruit (SC (L.) skeels) were reported. The study suggested the presence of following active principles from the edible parts of the fruit. Out of 74 individual phenolics found in the edible parts of jambolan, mainly in the skin, Anthocyanins, gallotannins and ellagitannins were focused as major phenolic components. High amounts of flavanols were also found in jambolan and jambolan flavonols derived from myricetin, laricitrin, and syringetin class. The condensed tannins were minor phenolic compounds and hydroxycinnamates were not found in the fruit. $^{4}$

Bioactivity-based fractionation and purification of methanolic extracts of SC seeds led to the isolation and identification of bifunctional vitalboside A. Methanol extract of SC seed's powder was subjected to solventsolvent fractionation by dissolving $60 \%$ methanol and partitioned with hexane and chloroform. The chloroform soluble fraction showed improved bioactivity which was subjected to column chromatography using silica gel. The F12 fraction from the column elution showed the best functional activity and concentrated F12 fraction was further analyzed by NMR, LC-MS and FTIR which enabled to the chemical structure for the vitalboside-A. Vitalboside-A exhibited anti-diabetic and anti-adipogenic activities by glucose uptake in L6 (rat myoblast), 3T3-L1 (mouse preadipocytes) adipocytes and Nile red assay. It inhibited the protein tyrosine phosphatase $1 \mathrm{~B}$ through the allosteric mechanism, which was later confirmed by docking studies. ${ }^{5}$

Column chromatographic separation of methanolic extract of SC seeds loaded on to silica gel column using gradient elution resulted in identification pale brown semisolid as active constituent. The compound was eluted from the column with $100 \%$ methanol elution and spectroscopic analysis confirmed as the isolated active principle as mycaminose. Mycaminose exhibited significant reduction in blood glucose levels at $50 \mathrm{mg} / \mathrm{kg}$ (15 days dosing) in streptozotocin (STZ) induced albino rats' diabetic model. ${ }^{6}$ 
Thus, methanolic extract of seeds appears to have a promising role as it is much investigated part among all the parts studied.

\section{PHARMACOLOGICAL ACTIVITY AND MECHANISM OF ACTION LINKED TO DIABETIC INTERVENTION}

SC has been evaluated in more than 100 research papers for antidiabetic activity using both in vitro and in vivo models. As far as in vivo models are concerned, the studies are mostly conducted on Alloxan or streptozotocin induced diabetes that mostly mimic type-1 diabetes. However, there are few studies on high fat diet and streptozotocin inducted diabetes that closely resembles type-2 diabetes. Experimentations are done on rats, rabbits and mice. The in vitro models are mainly used to demonstrate the site or targets of anti-diabetic action such as $\alpha$-glucosidase, $\alpha$-amylase, peroxisome proliferatorsactivated receptor $\gamma$, uptake of glucose by adipocytes or muscle cells, release of insulin by insulinoma cells etc. They have also been used to demonstrate the alteration in the intracellular signaling pathways by SC extract such as inhibition of protein tyrosine phosphatase (PTP1B).

\section{IN VITRO STUDIES}

\section{Inhibition of protein tyrosine phosphatase}

PTP1B is an endoplasmic enzyme involved in regulation of insulin and leptin signaling pathway ${ }^{8}$. Over expression PTP1B in adipose tissue and muscle leads to down regulation of $\mathrm{PI} 3 \mathrm{~K} / \mathrm{Akt} / \mathrm{Glut} 4$-signaling pathway, and the decrease in PTP1B protein expression level enhances the activity of the main components of insulin signaling. ${ }^{9}$ Scientific study has shown that bioactivity based fractionation and purification of methanol extract of SC seed (SCME) led to the isolation of Vitalboside A (VBA) as a bioactive phytochemical. ${ }^{5}$ The SCME and isolated VBA selectively inhibited protein tyrosine phosphatase (PTP1B) with $83 \%$ and $56 \%$ inhibition of PTP1B at 1 and $1.6 \mu \mathrm{m}$ respectively in an in vitro assay. It has been postulated that VBA inhibits PTP1B via an allosteric mechanism, which was later confirmed by docking studies. The study also showed that both SCME and VBA demonstrated insulin-stimulated glucose uptake in 3T3$\mathrm{L} 1$ and L6 cells at $1 \mu \mathrm{g} / \mathrm{ml}$ concentration. This increase in glucose uptake activity of VBA through insulinstimulated activation of PI3K establishes its insulinsensitizing potential through PTP1B inhibition. ${ }^{5}$

\section{Peroxisome proliferator-activated receptor ractivity}

Peroxisome proliferator-activated receptor $\gamma$ (PPAR- $\gamma$ ) is an important transcription factor that plays key a role in the regulation of glucose homeostasis, adipogenesis and lipid metabolism. PPAR- $\gamma$ agonists such as thiazolidinediones (e.g. pioglitazone) are considered to be important drugs for the management of insulin resistance and hyperglycemia in type 2 diabetes intervention.
Selective partial PPAR agonists capable of inducing activation of suboptimal receptors with reduced side effects could be valuable treatment option and will help in reducing adverse effects associated with existing thiazolidinediones. ${ }^{10}$ Studies by Thiyagarajan et al have shown that methanolic extract of SC seed and its isolated active constituent, VBA exhibited $56 \%$ and $52 \%$ inhibition of PPAR $\gamma-2$ transactivation at $1 \mu \mathrm{g} / \mathrm{mL}$ and 1.6 $\mu \mathrm{M}$ concentration, respectively compared to GW9662 (10 $\mu \mathrm{M})$ that showed $80 \%$ inhibition of PPAR $\gamma-2 .{ }^{5}$ This study also linked partial PPAR $\gamma$ agonism of SCME and VBA to reduction in lipid accumulation in 3T3-L1 adipocytes with enhanced adiponectin secretion. Thus, it appears that SC methanolic seed extract with partial PPAR $\gamma$ agonist activity may be useful as insulin sensitizer for management of type 2 diabetes.

Another study using an aqueous extract of SC seeds showed that diabetic rats treated with this extract exhibited increased level of PPAR $\gamma$ and PPAR $\alpha$ protein expressions in hepatic tissues from diabetic rats. ${ }^{11}$ This has been confirmed with in vivo experiments where 200 and $400 \mathrm{mg} / \mathrm{kg}$ of SC extract significantly increased PPAR $\gamma$ expression in diabetic rats compared to normal control group post 21 days of treatment.

\section{Inhibition of $\alpha$-glucosidase activity}

Glucosidases are the class of enzyme present in the brush border of the surface of intestine cells which catalyze the cleavage of glycosidic bonds in oligosaccharides or glycol-conjugates and thus convert them into monosaccharide. Hence, inhibition of $\alpha$-glucosidase enzyme will retard the digestion and absorption of carbohydrates and will be beneficial in diabetic treatment. $^{12}$ Different parts of SC plant have been reported to have $\alpha$-glucosidase inhibitory activity.

The aqueous extract of SC seed has shown inhibition $\alpha$ glucosidase activity with IC50 $8 \mathrm{mg} / \mathrm{ml}$. The biologically active extract further purified and isolated the active constituent responsible for $\alpha$-glucosidase inhibition as apigenin 7-O-glucoside. ${ }^{13}$

Another study using the active compounds isolated from ethyl acetate extract of SC leaves through chromatographic separation inhibited the $\alpha$-glucosidase enzyme with an IC50 of $28.20 \mu \mathrm{g} / \mathrm{ml}$. The bioactive fraction exhibited 3:1 mixture of ursolic acid and oleanolic acid. The pure ursolic acid and oleanolic acid showed IC50 values of 3.1 and $44.1 \mu \mathrm{g} / \mathrm{ml}$ respectively, against $\alpha$-glucosidase. ${ }^{14}$

Isolation and structural characterization of active constituents from methanolic extracts of SC seeds led to the identification of three new hydrolysable tannins. One of the characterized tannins exhibited very potent $\alpha$ glucosidase inhibition with IC50 value of $8.3 \mathrm{uM}$, which is 25 times stronger inhibitor than clinical agent, acarbose used as standard in the assay. ${ }^{15}$ These findings suggest 
that inhibition $\alpha$-glucosidase enzyme by bioactive constituents of SC seeds play vital role in antidiabetic therapy. Thus, seeds appear to have more potency in this activity than the leaves.

\section{Inhibition of adenosine deaminase activity}

Adenosine plays a significant role in modulation of insulin action on glucose metabolism in different tissues, and its levels are regulated by a ubiquitous enzyme called adenosine deaminase (ADA) found in many mammalian tissues. ${ }^{16}$ It has been shown that ADA activity is elevated during diabetes with hyperglycemia and correlates positively with glucose levels. ${ }^{17}$ The aqueous extract of SC seed showed the reversal of increased ADA levels in serum and kidney tissue from diabetic rats when treated with $100 \mathrm{mg} / \mathrm{kg}$ of SC seed extract for 21 days compared to the diabetic group. Amelioration of ADA activity may lead to increased adenosine levels which in turn had a positive impact in controlling the serum glucose level, decreased HOMA-IR index, total cholesterol and triglycerides. ${ }^{18}$

Another study has shown that the aqueous extract of SC leaves was very efficient in preventing the increased levels of erythrocytic ADA level under in vitro hyperglycemic conditions from blood samples from the healthy volunteers. ${ }^{19}$ All three concentrations of SC leave extracts $(100,200$ and $300 \mu \mathrm{g} / \mathrm{ml})$ prevented the increase in the ADA activity in hyperglycemic conditions when RBCs were exposed to $30 \mathrm{~mm}$ glucose. These findings indicate that the aqueous extract of SC leaves and seeds have the positive impact in controlling serum glucose, lipid profile and HOMA-IR index through adenosine pathway.

\section{Inhibition of $\alpha$-amylase activity}

The $\alpha$-amylase activity is interconnected with post prandial blood glucose level, and insulin action as this is an essential enzyme necessary for breaking down of starch into oligosaccharides and disaccharides in the intestine. Hence inhibition of $\alpha$-amylase will be in useful in controlling post prandial blood glucose level in diabetic and obese subjects. ${ }^{20}$ Bioassay-guided fractionation study using ethyl acetate extract of SC leaves through chromatographic separation inhibited the $\alpha$-amylase enzyme with an IC50 of $39.9 \mu \mathrm{g} / \mathrm{ml}$. The bioactive fraction exhibited 3:1 mixture of ursolic acid and oleanolic acid. The pure ursolic acid and oleanolic acid showed IC50 values of 6.7 and $57.4 \mu \mathrm{g} / \mathrm{ml}$ respectively, against $\alpha$-amylase. ${ }^{14}$

\section{In vitro insulin secretion}

Quercetin, a flavonoid known to present in SC leaves as active constituent stimulates the insulin release via direct activation of L-type calcium channel. ${ }^{21}$ Based on this hypothesis, a recent study has shown that the hydroethanolic extract of SC leaves enhanced insulin secretion in response to an addition of exogenous glucose under in vitro condition using rat insulinoma derived INS$1 \mathrm{E}-\beta$ cells. The best insulin secretion effect was observed for $100 \mu \mathrm{g} / \mathrm{ml}$ hydroethanolic extract in INS-1E cells at $3.3 \mathrm{~mm}$ and $16.7 \mathrm{~mm}$ glucose concentrations. However, the highest level of $(1000 \mu \mathrm{g} / \mathrm{ml})$ SC extract showed decreased insulin secretion effect, and this could be due to the cytotoxicity associated with high concentration. ${ }^{2}$

\section{IN VIVO STUDIES FOR ANTI-DIABETIC ACTIVITY}

The various parts of SC were investigated for antidiabetic potential in animal models and the bark, leaves, fruit pulp and seeds were found to be effective in controlling experimental diabetes. The antidiabetic effects of $S C$ are demonstrated in alloxan and streptozotocin-induced models of type1 diabetes as well as high fat diet -low dose STZ, monosodium L-glutamate (MSG) and fructoseinduced models of Type II diabetes. Among the plant parts studied, the seed has found to be very vastly studied and demonstrated to have potent hypoglycemic effects in a number of preclinical studies.

\section{Seed extract}

Administration of three doses of aqueous extract of SC seeds $(100,200,400 \mathrm{mg} / \mathrm{kg})$ to HDF-STZ induced diabetic male albino rats for 21 days showed lowering of serum glucose, reduced insulin resistance (HOMA-IR) and improved beta cell dysfunction (HOMA-B) in dose dependent manner. ${ }^{11}$ The best antidiabetic effects (serum glucose, HOMA-IR and HOMA-B) were observed at 400 $\mathrm{mg} / \mathrm{kg}$ of $\mathrm{SC}$ and $100 \mathrm{mg} / \mathrm{kg}$ of metformin groups when compared with untreated diabetic control group.

Studies aimed at exploring the antidiabetic activity of ethyl acetate extract of SC seeds in short-term and longterm STZ induced albino rat models resulted in restoring of fasting blood glucose levels in treatment group compared to diabetic control group. ${ }^{22}$ Administration of single dose of $200 \mathrm{mg} / \mathrm{kg}$ of SC extract in acute model attenuated the fasting blood glucose levels up to $8 \mathrm{hrs}$ and the effect was comparable to standard drug glibenclamide $20 \mathrm{mg} / \mathrm{kg}$ single dose effect in the same study. Daily dosing of $200 \mathrm{mg} / \mathrm{kg}$ of SC extract for 35 days in longterm model showed significant reduction in FBG and restored the serum insulin level to normal control level. ${ }^{22}$

Recent studies using hydro-alcoholic and methanolic extracts of SC seeds in Alloxan-induced diabetic rat model shown positive results in lowering blood glucose levels. Hydro-alcoholic exhibited antidiabetic effect at $500 \mathrm{mg} / \mathrm{kg}$ dose and significantly reduced the blood glucose level after 21 days of treatment. ${ }^{23}$ The methanolic extract study using $200 \mathrm{mg} / \mathrm{kg}$ for 14 days showed comparable blood glucose lowering effect as that of gliclazide $25 \mathrm{mgkg}$ dose in comparison with diabetic control group. ${ }^{24}$ 


\section{Leaves extract}

Studies using hydroethanolic extract of SC leaves in lean and MSG-induced obese rat model showed improved hyperinsulinemia and insulin resistance. Administration at a dose of $500 \mathrm{mg} / \mathrm{kg}$ for 30 days period showed a significant reduction in body weight gain, body mass index, and white adipose tissue mass, improved hyperinsulinemia and insulin resistance in obese rats treated with hydroethanolic extract of SC leaves (HESc).

Hydroethanolic extract of leaves also potentiated pancreatic function in islets via stimulating/modulating $\beta$ cell insulin release isolated from both lean and obese rats which resulted in partial reversal of glucose intolerance. It also has been reported there was an improvement in peripheral insulin sensitivity, which was associated with improvements in metabolic outcomes in MSG-induced obese rats. ${ }^{2}$

Evaluation of hydro alcoholic extract of SC leaves using a high-fat diet and low dose streptozotocin-induced diabetic model exhibited serum hypoglycemic activity. The study also demonstrated that aerobic exercise in diabetic rats resulted in beneficial effects on diabetes, improved functional capacity, and lowered the blood triglyceride and decreasing lipid peroxidation. However, the exercise did not have any effect on blood glucose level. ${ }^{25}$

\section{Bark extract}

Four different solvent extracts (petroleum ether chloroform, ethanol and aqueous) of SC bark evaluated for antidiabetic activity in STZ induced diabetic rat model using $500 \mathrm{mg} / \mathrm{kg}$ dose for 21 days. Among the four extracts studied, the ethanolic and aqueous extract showed a significant effect (125.4 and $119.23 \mathrm{mg} / \mathrm{dl})$ in the reduction of fasting glucose level when compared with diabetic control group $(268.46 \mathrm{mg} / \mathrm{dl})$. The standard drug glibenclamide $2.5 \mathrm{mg} / \mathrm{kg}$ used in the study lowered fasting glucose to $106.33 \mathrm{mg} / \mathrm{dl}^{26}$

\section{Comparison of all parts of the plant}

The methanolic and aqueous extracts of different parts of SC (roots, leaves, barks and seeds) were evaluated for antidiabetic potential using alloxan monohydrate induced male Sprague-Dawley (SD) rat model. All four extracts have showed statistically significant blood glucose lowering effect at $100 \mathrm{mg} / \mathrm{kg}$ dose post 21 days of treatment. A confirmatory study with aqueous extract of SC leaves using both alloxan and STZ induced rat model further showed significant fasting glucose lowering effect at $200 \mathrm{mg} / \mathrm{kg}$ after 21 days of treatment. The effect was better than $500 \mathrm{mg} / \mathrm{kg}$ dose of metformin used in the same study. ${ }^{27}$

Poly-herbal formulation (MAC-ST/001) composition comprising of aqueous SC seeds (20\% of formulation) plus four other medicinal plants were shown to be very effective in reversing the hyperglycemia induced by STZ in albino Wistar rats after 4 weeks of treatment. The effect of $400 \mathrm{mg} / \mathrm{kg}$ dose of MAC-ST/001 was superior than 10 $\mathrm{mg} / \mathrm{kg}$ of glibenclamide used in the study as standard control. $^{28}$

\section{ACUTE AND SUB-ACUTE TOXICITY STUDIES}

Thorough toxicological profiling of plant extract in preclinical models is essential to ensure safety and tolerability of the extract for human use. The following recent studies using both mice and rats suggest that the plant's parts and its various extracts are safe to use in a clinical set-up.

\section{Toxicity studies with SC bark extract}

Evaluation of acute and repeat oral toxicity studies for aqueous extract of SC barks at various doses in both mice and rat as per OECD guidelines were reported. ${ }^{29}$ The results from acute toxicity using mice (both sex) suggested that the extract was well tolerated up to 5000 $\mathrm{mg} / \mathrm{kg}$ and no mortality or signs of toxicity were reported at the highest dose studied. Hence maximum tolerated dose (MTD) was found to be $5000 \mathrm{mg} / \mathrm{kg}$ for the aqueous extract of SC barks. Repeat oral toxicity study involving $300,1000,2000 \mathrm{mg} / \mathrm{kg}$ of the extract in Wistar rats for 28 days reported to be well tolerated. No mortality or toxicity or significant changes in general behavior and physiological activities were observed during the study and as well post treatment period up to 14 days. Both female and male rats behaved very well with no changes in body weight and normal food/water intake. No significant changes in hematological and biochemical parameters were observed post 28 days of dosing in comparison to normal control group. This study provides sufficient preclinical evidence of safety for aqueous extract of SC stem bark.

Acute toxicity study of petroleum ether, chloroform, ethanol and aqueous extracts SC stem bark using Wistar rats suggest that all four extracts were well tolerated up to $5000 \mathrm{mg} / \mathrm{kg}$ dose by the oral route. None of the extracts studied have shown any sign of toxicity or mortality during the one-week observation period. ${ }^{26}$

\section{Toxicity studies with SC leaves extract}

Acute toxicity studies to determine the LD50 of hydroalcoholic (HE) extract of SC leaves in mice and rat by oral and intra-peritoneal (IP) routes were reported. Oral administration of HE extracts well tolerated up to $6 \mathrm{~g} / \mathrm{kg}$ in mice and $2 \mathrm{~g} / \mathrm{kg}$ in rats with no deaths. However, the intra-peritoneal route administration of $\mathrm{HE}$ extracts in mice caused death of animal and the reported LD50 for mice is $0.489 \mathrm{~g} / \mathrm{kg}$ by route. In the case of rat, only $2 \mathrm{~g} / \mathrm{kg}$ dose found to be lethal to $67 \%$ animal by IP route.

Chronic toxicity study of HE extracts of leaves in rats for 30, 90 and 180 days found to be well tolerated among the 
three-dose group examined $(50,100,250 \mathrm{mg} / \mathrm{kg})$ with no change in body weight and food intake. Also, biochemical analysis and histopathological finding post 30 days treatment showed some changes in biochemical parameters but no morphological disturbances with respect to liver, kidney, heart, lung, stomach and intestine. $^{30}$

\section{Toxicity studies with SC seed extract}

Acute toxicity studies involving ethyl acetate and methanol extracts of SC seeds in rats as per OECD423 guidelines found to be safe up to the dose of $2 \mathrm{~g} / \mathrm{kg}$ with no mortality. ${ }^{6}$

Evaluation of aqueous extract of SC seed for acute toxicity profiling suggest that single dose of 500 $\mathrm{mg} / \mathrm{ml} / \mathrm{kg}$ of the extract was well tolerated with no clinical signs of toxicity or deaths were reported during the monitoring period (up to 14 days). There was no change in food intake, body weight, biochemical and hematological parameters in comparison to normal control group. ${ }^{31}$

\section{CLINICAL STUDIES}

The use of Jamun plant parts are well known for therapeutic intervention of diabetic mellitus and its associated complications for human use in Ayurveda and other folklore medical system since long. However, very few studies are carried out to establish scientific evidence of therapeutic potential of Jamun in human. The reason for this could be paucity of adequate data on the safety of extract, choice of extract and on the dose to be tried. The following clinical trial studies have been done using the crude powder using SC plant parts and are recently reported in the literature.

A double-blind study with a tea prepared from SC leaves found to have no significant effect on lowering blood glucose and concluded the tea is pharmacologically inert in a double-blind, double dummy, randomized clinical trial. ${ }^{32}$

In an open labeled, randomized, parallel designed control trial, 15 newly diagnosed type 2 DM patients were administered with SC seed-based drug as Madhuhara Churna for period of 3 months. The study results suggested that the investigational drug showed significant effects in reduction of fasting blood glucose, insulin resistance and increased HDL level at the end three months treatment but the drug did not have any impact on post prandial glucose and glycated hemoglobin contents at end of both 3 and 6 months of treatments. There were no change in triglycerides, LDL, total cholesterol in comparison to baseline. ${ }^{33}$

A recent clinical trial study using 49 patients diagnosed with type $2 \mathrm{DM}$ in a double blind randomized controlled trial administered with $10 \mathrm{~g} /$ day SC seed powder over 90 days period for lowering of high blood pressure associated with type $2 \mathrm{DM}$ condition. Finding from this clinical trial study suggested that jamun seed powder exhibits blood pressure lowering effect and significantly lowered the blood pressure associated with patients with type 2 diabetes mellitus in addition to its known blood sugar lowering effects and improves overall health of diabetic patients. ${ }^{34}$

The above studies indicate that crude drug powder of SC shows beneficial antidiabetic activity and is well tolerated but needs a higher dose. Such doses may not be practically implementable. Hence trials need to be conducted on the suitable extracts after thorough toxicity studies.

\section{CONCLUSION}

As per the above observation seed extracts are most widely investigated particularly the ethanolic / methanolic extracts. It has shown promising results in lowering blood glucose level and improving the insulin sensitivity. A dose of $200 \mathrm{mg}$ and $400 \mathrm{mg} / \mathrm{kg}$ is found to be effective. Its probable mechanism of action appears to be inhibition of alpha glucosidase and increased uptake of glucose by muscle and adipocytes. Clinical trials have also shown that the seed powder to be efficacious this is followed by HESc which also shown promising results in hyperinsulinemia and insulin resistances. It is therefore worthwhile to undertake studies for head to head comparisons of these two extracts at similar dosages to arrive at the effective formulations.

\section{Funding: No funding sources \\ Conflict of interest: None declared \\ Ethical approval: Not required}

\section{REFERENCES}

1. Ayyanar M, Subash-Babu P. Syzygium cumini (L.) Skeels: A review of its phytochemical constituents and traditional uses. Asian Pac J Trop Biomed. 2012;2(3):240-6.

2. Sanches JR, França LM, Chagas VT, Gaspar RS, dos Santos KA, Gonçalves LM, et al. Polyphenol-Rich extract of Syzygium cumini leaf dually improves peripheral insulin sensitivity and Pancreatic Islet function in monosodium 1-glutamate-induced obese rats. Front Pharmacol. 2016;7:48.

3. Poongunran J, Perera HKI, Jayasinghe L, Fernando IT, Sivakanesan R, Araya H, Fujimoto Y. Bioassayguided fractionation and identification of $\alpha$-amylase inhibitors from Syzygium cumini leaves. Pharm Biol. 2017;55(1):206-11.

4. Tavares IM de C, Lago-Vanzela ES, Rebello LPG, Ramos AM, Gómez-Alonso S, García-Romero E, et al. Comprehensive study of the phenolic composition of the edible parts of jambolan fruit (Syzygium cumini (L.) Skeels). Food Research International. 2016;82:1-13. 
5. Thiyagarajan, G., Muthukumaran, P., Sarath Kumar, B., Muthusamy, V.S., Lakshmi, B.S. Selective inhibition of PTP1B by Vitalboside A from Syzygium cumini Enhances insulin sensitivity and Attenuates lipid accumulation via partial Agonism to PPAR $\gamma$ : In Vitro and In Silico Investigation. Chem Biol Drug Des. 2016; 88(2):302-12.

6. Kumar, A., Ilavarasan, R., Jayach, T., Deecaraman, M., Aravindan, P., Padmanabhan, N., Krishan, M.R.V. Anti-diabetic activity of syzygium cumini and its isolated compound against streptozotocininduced diabetic rats. J Med Plants Res. 2008;2(9):246-9.

7. Crandall JP, Knowler WC, Kahn SE, Marrero D, Florez JC, Bray GA, et al. The prevention of type 2 diabetes. Nat Clin Pract Endocrinol Metab. 2008;4(7):382-93.

8. Bence KK, Delibegovic M, Xue B, Gorgun CZ, Hotamisligil GS, Neel BG, et al. Neuronal PTP1B regulates body weight, adiposity and leptin action. Nat Med. 2006;12(8):917-24.

9. Rondinone CM, Trevillyan JM, Clampit J, Gum RJ, Berg C, Kroeger P, et al. Protein tyrosine Phosphatase $1 \mathrm{~B}$ reduction regulates Adiposity and expression of genes involved in Lipogenesis. Diabetes. 2002;51(8):2405-11.

10. Weidner C, de Groot JC, Prasad A, Freiwald A, Quedenau C, Kliem M, et al. Amorfrutins are potent antidiabetic dietary natural products Proc Natl Acad Sci U S A. 2012;109(9):7257-62.

11. Sharma AK, Bharti S, Kumar R, Krishnamurthy B, Bhatia J, Kumari S, et al. Syzygium cumini ameliorates insulin resistance and $\beta$-cell dysfunction via modulation of PPAR, dyslipidemia, oxidative stress, and TNF- $\alpha$ in type 2 diabetic rats. J Pharmacol Sci. 2012;119(3):205-13.

12. Borges de Melo, E, da Silveira Gomes, A, Carvalho, I. $\alpha$ - and $\beta$-glucosidase inhibitors: Chemical structure and biological activity. Tetrahedron 2006;62(44):10277-302.

13. Alagesan, K, Thennarasu, $\mathrm{P}$, Kumar, V, Sankarnarayanan, S, Balsamy, T. Identification of $\alpha$ glucosidase inhibitors from Psidium guajava leaves and Syzygium cumini Linn. Seeds. Int J Pharma Sci Res. 2012;3(2):316-322

14. Poongunran J, Perera HKI, Jayasinghe L, Fernando IT, Sivakanesan R, Araya H, et al. Bioassay-guided fractionation and identification of $\alpha$-amylase inhibitors from Syzygium cumini leaves. Pharm Biol. 2017;55(1):206-11.

15. Omar R, Li L, Yuan T, Seeram NP. $\alpha$-Glucosidase inhibitory Hydrolyzable Tannins from Eugenia jambolana Seeds. J Nat Prod. 2012;75(8):1505-9.

16. Haskó G. Adenosine: An endogenous regulator of innate immunity. Trends Immunol. 2004;25(1):33-9.

17. Bopp A, Bona D, Bellé LP, Moresco RN, Moretto MB. Syzygium cumini inhibits adenosine deaminase activity and reduces glucose levels in hyperglycemic patients. Fundam Clin Pharmacol. 2009;23(4):501-7.
18. Bitencourt PER, Bona KSD, Cargnelutti LO, Bonfanti G, Pigatto A, Boligon A, et al. Syzygium cumini seed extract ameliorates adenosine deaminase activity and biochemical parameters but does not alter insulin sensitivity and pancreas architecture in a short-term model of diabetes. J Complement Integr Med. 2015;12(3):187-93.

19. De Bona KS, Bonfanti G, Bitencourt PER, Cargnelutti LO, da Silva PS, da Silva TP, et al. Syzygium cumini is more effective in preventing the increase of erythrocytic ADA activity than phenolic compounds under hyperglycemic conditions in vitro. J Physiol Biochem. 2014;70(2):321-30.

20. Alagesan K, Raghupathi K, Sankarnarayanan S. Amylase inhibitors: Potential source of anti-diabetic drug discovery from medicinal plants. Int J Pharm Life Sci. 2012;3(2):1407-12

21. Bardy G, Virsolvy A, Quignard JF, Ravier MA, Bertrand G, Dalle S, et al. Quercetin induces insulin secretion by direct activation of $\mathrm{L}$ type calcium channels in pancreatic beta cells. Br J Pharmacol. 2013;169(5):1102-13.

22. Jana K, Bera TK, Ghosh D. Antidiabetic effects of Eugenia jambolana in the streptozotocin-induced diabetic male albino rat. Biomarkers and Genomic Medicine. 2015;7:116-24.

23. Saifi A, Chauhan R, Dwivedi J. Assessment of the antidiabetic activity of Syzygium cumini (Linn.) Skeels in alloxan induced diabetic rats. Res. J. Pharmacol Pharmacodynam. 2016;8(3):91-6.

24. Nahid S, Mazumder K, Rahman Z, Islam S, Rashid $\mathrm{MH}$, Kerr PG. Cardio- and hepato-protective potential of methanolic extract of Syzygium cumini (L.) Skeels seeds: A diabetic rat model study. Asian Pac J Trop Biomed. 2017;7(2):126-33.

25. Baldissera G, Sperotto ND, Rosa HT, Henn JG, Peres VF, Moura DJ, et al. Effects of crude hydroalcoholic extract of Syzygium cumini (L.) Skeels leaves and continuous aerobic training in rats with diabetes induced by a high-fat diet and low doses of streptozotocin. J Ethnopharmacol. 2016;194:1012-21.

26. Tripathi AK, Kohli S. Pharmacognostical standardization and antidiabetic activity of Syzygium cumini (Linn.) barks (Myrtraceae) on streptozotocininduced diabetic rats. J Complement Integr Med. 2014;11(2):71-81.

27. Deb, L, Bhattacharjee, C, Shetty, R.S, Dutta, A. Evaluation of anti-diabetic potential of the syzygium cuminii (linn) skeels by reverse pharmacological approaches. Bulletin Pharm Res. 2013;3(3):135-45.

28. Yadav D, Chaudhary AA, Garg V, Anwar MF, Rahman MM, Jamil SS, et al. In vitro toxicity and antidiabetic activity of a newly developed polyherbal formulation (MAC-ST/001) in streptozotocininduced diabetic Wistar rats. Protoplasma. 2013;250(3):741-9.

29. Yele SU, Veeranjaneyulu A. Toxicological assessments of aqueous extract of Eugenia Jambolana stem bark. Pharm Biol. 2010;48(8):849-54. 
30. Silva S do N, Abreu IC, Silva GFC, Ribeiro RM, Lopes A de S, Cartágenes $\mathrm{M}$ do $\mathrm{S}$ de $\mathrm{S}$, et al. The toxicity evaluation of Syzygium cumini leaves in rodents. Rev. bras. Farmacogn. 2012;22(1):102-8.

31. Bitencourt PER, Ferreira LM, Cargnelutti LO, Denardi L, Boligon A, Fleck M, et al. A new biodegradable polymeric nanoparticle formulation containing Syzygium cumini: Phytochemical profile, antioxidant and antifungal activity and in vivo toxicity. Industrial Crops Products. 2016;83:400-7.

32. Teixeira CC, Fuchs FD, Weinert LS, Esteves J. The efficacy of folk medicines in the management of type 2 diabetes mellitus: Results of a randomized controlled trial of Syzygium cumini (L.) Skeels. J Clin Pharm Ther. 2006;31(1):1-5.

33. Baliga MS, Fernandes S, Thilakchand KR, D'souza $\mathrm{P}, \mathrm{Rao}$ S. Scientific validation of the Antidiabetic effects of Syzygium jambolanum DC (black plum), a traditional medicinal plant of India. J Altern Complement Med. 2013;19(3):191-7.

34. Sidana S, Singh V, Meena B, Beniwal S, Chandra S, Singh, K, et al. Effect of Syzygium cumini (jamun) seed powder on dyslipidemia: A double blind randomized control trial. Int $\mathbf{J}$ Res Med Sci. 2016;4(7):2603-10.

Cite this article as: Asanaliyar M, Nadig P.

Syzygium cumini (jamun) therapeutic potential: a comprehensive review on phytochemical constituents and emphasis on its pharmacological actions related to diabetic intervention. Int J Basic Clin Pharmacol 2020;9:363-70. 